\title{
State and Legal Regulation of the Flow of Media Information about Coronavirus Infection COVID-19
}

\author{
Nailya Akhmetyanova ${ }^{1},{ }^{*}$ Iuliia Saitbattalova ${ }^{1}$, Ekaterina Poliakova ${ }^{1}$ \\ ${ }^{1}$ Bashkir State University, Ufa, Russia \\ *Email: $\underline{\text { ANailaA@yandex.ru }}$
}

\begin{abstract}
The article examines the quality of informing the population by the mass media about the new coronavirus infection (COVID-19) based on the publications of online and print publications of the Republic of Bashkortostan. The purpose is to determine their role in forming ideas about the ongoing processes in the region's healthcare sector. The study conducted by the authors is an attempt to identify the problem of providing high-quality information about the new coronavirus infection (COVID-19) and medicine in the media of the Republic of Bashkortostan. The analysis of empirical and metric materials that form the basis of the study shows that over time the problem of disinformation does not disappear; on the contrary, new aspects of it appear, which Republican journalists overcome with difficulty. In this regard, decisive measures are needed on the part of the government, the adoption of new legal norms regarding broadcast information. In the fight against disinformation and avoiding disseminating information from unreliable sources, editorial offices need to cooperate closely with reputable medical organisations and specialists. The study results allow us to conclude that the media of the Republic of Bashkortostan of the Russian Federation have not yet developed a fullfledged algorithm of interaction not only with the audience but also with the authorities in matters of covering this agenda. They face the difficult task to deliver only reliable and verified information to their consumers.
\end{abstract}

Keywords: Mass media, Pandemic, COVID-19, Disinformation, Coronavirus infection, Vaccination, Healthcare.

\section{INTRODUCTION}

Healthcare problems have always been the subject of constant attention: discussions in the mass media, scientific press, and legislative bodies are devoted to them. One of today's acute social issues and topical problems affecting medicine is COVID-19. COVID-19 is a 2019 coronavirus infection caused by the SARS-CoV2 virus. Due to the rapid spread of information about a new disease from various sources, including unverified ones, the population is becoming a victim of misinformation. Studies conducted earlier show this phenomenon due to the collapse of social solidarity and the decline in Russian medicine status [1,2]. The purpose of the study is an attempt to reveal the specifics of the problems associated with the coverage of the field of medicine in the mass media of the Republic of Bashkortostan in the context of the COVID-19 pandemic and to identify the role of the mass media not only in combating it and disinformation but also in the forming ideas about the ongoing processes in the healthcare sector of the region.

\section{RESEARCH METHODOLOGY}

This article is based on publications of socio-political newspapers of the Republic of Bashkortostan (hence RB) in Russian, Bashkir and Tatar languages; special reviews of the European External Action Service (hence - EEAS), reports on the results of the work of the Ministry of Health of the Republic for 2020-2021, research literature, which reflects the main directions of studying the activities of various social institutions. As the primary research method, the authors used qualitative and quantitative content analysis of materials published over 2020-2021 in print and online versions of the media of the Republic of Belarus. This study analyses the media officially registered with the Federal Service for 
Supervision of Communications, Information Technology and Mass Communications (hereinafter: Roskomnadzor) and having the appropriate state licenses; all others were not considered in the context of this work.

\section{THE ROLE OF THE MEDIA IN INFORMING THE POPULATION DURING THE PANDEMIC}

The media's mission during the pandemic is to provide information that will be in demand by the population ahead of rumours. If people do not have reliable information, it will be challenging to make the right choice $[3,4]$. Their choice should be based on highquality information, trust in facts and figures. The current conditions of the fight against disinformation have brought about clear changes in the sphere of society's life. Scientific sources note that such changes once again showed the imperfection of the current legislation, and therefore there was a need to create a new, previously non-existent legal framework for optimal regulation of current legal relations $[5,6]$. According to the results of this study, since the beginning of the pandemic (March 2020), the amount of unreliable information in the media of the Republic of Belarus regarding COVID-19 and its consequences has decreased slightly, and the focus has shifted to vaccines (September 2021), also generating a lot of new rumours and myths.

\section{ANALYSIS OF COVID-19 COVERAGE IN THE MEDIA OF THE REPUBLIC OF BASHKORTOSTAN}

Rumours often appear in moments of social tension, as we see with the example of a pandemic. They give a person answers to questions to one degree or another and help to take action since their task is a collective solution to the problem that has arisen $[3,6]$. The spread of the new coronavirus infection was accompanied by a massive "information pandemic", which the World Health Organisation (hence - WHO) presents as an overabundance of unreliable and erroneous information, significantly burdening the selection of truthful and trustworthy sources [7]. These messages, as a rule, contained information about what the new virus "really" is ("this is a bioweapon of China", "this is a common flu", etc.), how to protect yourself from it (drink vodka, apply ginger) and, finally, about the consequences of quarantine and vaccination ("we will all be chipped") [8]. Russians' interest in such stories is often associated with a drop in confidence in government institutions and official sources of information [8]. In this regard, the Board of Directors of the social networks Facebook, Google, LinkedIn, Microsoft, Reddit, Twitter, YouTube, Twitter, TikTok, Snapchat, Pinterest, Viber, WhatsApp published a joint statement on close cooperation with WHO, developing ways to combat the spread of false information and misinformation about the COVID-19 coronavirus on their platforms [9].

The novelty of the virus and its lack of knowledge causes the population to fear the unknown. Scientific sources note that experiencing fear of COVID-19 disease makes people susceptible to fake news [10;3]. In addition, the catalyst for the perception of information was the instinct of self-preservation against the background of an increase in deaths. The past two years since the emergence and spread of this virus in the world have not reduced interest in this topic. According to "Yandex" statistics in November 2021, the word "coronavirus" was searched by 54,568,419, Google - 98 million 300 thousand users. Another 49 positions of the top searches are occupied by phrases in which the word "coronavirus" is present $[11,12]$.

In the Republic of Bashkortostan, there have been cases when the flow of disinformation has manipulated more susceptible people. The proof is acts of vandalism and outbursts of discontent among the residents of the Abzelilovsky district, Ufa, who took one of the myths for faith. The pages of printed and online publications of the Republic of Bashkortostan were full of click baits: "In Bashkiria, people knocked down a 5G tower!" (AIFUfa), "Ufa residents fear for their health because of a suspicious tower" (KP-Ufa), "Villagers were afraid of "radiation" from 5G and demolished a cell tower" (Lenta.ru), "In Russia, villagers demolished a cell tower with a tractor so that it would not radiate" (Cnews.ru) and others. The reaction from the mass media to this event was different. While some, covering the events about acts of vandalism, attempted to refute misinformation about the health harm of cell towers, because "Many believe that with the help of $5 \mathrm{G}$ towers they want to infect them with coronavirus or subjugate someone else's will"; other news portals claim that the population of Bashkortostan is in a "trend" and do not lag behind the Europeans: "Such a fight with communication towers is not new. In the spring of 2020, 77 cell towers were burned in England. The British have decided that the spread of the coronavirus relates to the spread of 5G technology." At the same time, the latter neglects that official media's use of disinformation methods does not contribute to maintaining order in society.

Let's consider a few more publications of online publications, websites of regional newspapers of the republic containing medical information, according to the method of submission that falls under unreliable: "In New York State, three children died from a mysterious syndrome caused by COVID-19" (Ufa News for everyone), "The WHO Director warned about the appearance of more dangerous variants of coronavirus" (the district newspaper "Krasny Klyuchnuriman"), "An antibody was found in the USA that completely blocks coronavirus" (KP-Ufa), "Mouthwash is able to protect from coronavirus infection" (ufatime.ru ). In each of 
them, the authors make gross mistakes. The lack of evidence and references to the research of reputable scientists, to the protocols of research institutions whose discoveries are in question, makes them pseudo-medical and false. Sometimes local district and city media, in order not to lose their audience or raise ratings, reprint information from other publications, websites, even from the pages of users of social networks. For example, in the note: "A doctor from the USA told about the pleas of patients dying from coronavirus to vaccinate them" (the district newspapers "Buzdyak News", "Baymaksky Vestnik", etc.), there is not a single active link to the source, although federal news portals refer to the website of the newspaper "Mirror" [13] and the doctor's Facebook page. This example of an incorrect note is a reprint of long reads from other media. For this reason, a certain amount of information from the original source is suppressed or reduced, which is why it is perceived as unreliable. Such information on medical topics misleads the reader and can cause material damage. To date, strict measures are being taken in the Russian Federation against websites and media whose content reveals violations or unverified information: during the period under review in Russia, "more than 4 thousand sites have been blocked, illegal messages have been deleted from 25 thousand resources" [14]. A list of information resources regularly distributing false information has appeared on the Roskomnadzor website. A law has been signed on imprisonment for up to five years for spreading deliberately false information about the SARS-CoV-2 coronavirus, which led to grave consequences [14]. In the republican media, there are materials about specific cases deployed in this direction, about fined citizens, drawn up protocols. For example, "In Bashkiria, a girl was fined for publishing about the coronavirus." "An administrative case was opened against a 26-year-old resident of the Karmaskalinsky district for fake news about the coronavirus. She was fined 15 thousand rubles" (Gorobzor.ru). Or, "doctors got caught on the forgery of vaccination certificates", "754 protocols were drawn up in Ufa for violation of anti-aids measures" [14].

As part of measures to combat the spread of COVID19 infection in the Republic of Bashkortostan in several directions at once, employees of the Ministry of Digital Development of the State Administration of the Republic of Bashkortostan organised and launched call centres for assistance and counselling: the situational centre for ensuring the sustainable functioning of the economy of the Republic of Bashkortostan, the hotline of the Ministry of Health of the Republic of Belarus on coronavirus infection. A situational anti-ovoid centre has been deployed.

In the Republic of Bashkortostan, medical workers and the media began to cooperate closely. New headings in the media "Scientists and doctors expose myths about coronavirus", "Health", "Stop coronavirus" become a platform where you can find reliable information. In the interdistrict newspaper, doctors dispel myths about the coronavirus, which some people still stubbornly believe in the publication "11 myths about the coronavirus that people still believe in" (the newspaper "On the land of Salavat"). Panorama magazine has chosen the proper position since the beginning of the pandemic and, together with experts from the Ministry of Health of Bashkortostan and well-known doctors, answers topical coronavirus questions and now about COVID-19 vaccination. The newspaper "Republic of Bashkortostan" has a permanent column "Question to the expert" the best doctors of the republic - Doctor of Sciences and practising physicians who have passed the "red zone" answer current medical questions. Everyday stories of ordinary people who have been ill with COVID-19, as well as stories related to vaccination, became popular on this agenda: "From denial to vaccination: stories of residents of Bashkiria" (information and news portal Gorobzor).

\section{CONCLUSIONS}

It is safe to say that COVID-19 has made an enormous contribution to the agenda of the regional media. The number of informational occasions for publications has increased significantly, as they have become the leading platforms for posting information about the situation in this direction. The interest in the media has significantly increased: the more news on this topic the publication posted on its page, the more views it secured. The analysis also shows that debunking myths around the emergence and spread of COVID-19 in Bashkortostan is generally successful. Effective strategies and tools to combat infodemia are being implemented with the help of the regional department of the Ministry of Health and the support of the regional authorities. Local media have developed methods and ways to combat disinformation: refute myths and provide reliable information. However, such a policy is being implemented with varying success. Thus, it can be concluded that today the media still faces a difficult task to prevent the spread of false medical information.

\section{REFERENCES}

[1] O.A. Shapovalova, The role of non-personal communication channels in forming a value attitude to health [Rol' kanalov nelichnoj kommunikacii $\mathrm{v}$ formirovanii cennostnogo otnosheniya $\mathrm{k}$ zdorov'yu], Materials of the reports of the XIV International Conference "Lomonosov" [Materialy dokladov XIV Mezhdunarodnoj konferencii «Lomonosov»], Publishing Center of the Faculty of Journalism of Moscow State University, Moscow 3 (2007) 528-529.

[2] A.V. Reshetnikov, Sociology of Medicine, Medicine, M., 2002, pp. 455-456. 
[3] D.I. Sadykov, N.A. Akhmetyanova, The spread of fake news during the COVID-19 pandemic, Colloquium-journal 8(60) (2020) 33-35. DOI: https://doi.org/10.24411/2520-6990-2020-11546

[4] N.A. Akhmetyanova, Role of Printed Publications in Ethnic Identification of Ethnic Groups In Bashkortostan, in Social and Cultural Transformations in the Context of Modern Globalism (SCTCMG 2021), European Publisher 117 (2021) 52-58. DOI: https://doi.org/10.15405/epsbs.2021.11.8

[5] D.K. Grigoryan, S.S. Gorshkolepov, Institutional restrictions on the part of the authorities in the regulation of the dissemination of deliberately false information: a case study of data on COVID-19, Theories and Problems of Political Studies 10(3A) (2021) 49-57. DOI: https://doi.org/10.34670/AR.2021.46.50.014

[6] E.B. Kozyreva, A.A. Demidenko, D.E. Mulyavko, Legal analysis of the experience of countering COVID-19 [Pravovoj analiz opyta protivodejstviya COVID-19], Innovations. Science. Education [Innovacii. Nauka. Obrazovanie] 12 (2020) 296301. Retrieved from: https://innovjourn.ru/

[7] Official website of the World Health Organisation. URL: https://www.who.int/ru/ (accessed: 02.12.2021).

[8] A.S. Arkhipova, D.A. Radchenko et al. The ways of the Russian infodemia: from WhatsApp to the Investigative Committee [Puti rossijskoj infodemii: ot WhatsApp do Sledstvennogo komiteta], Monitoring Public Opinion: Economic and Social Changes [Monitoring obshchestvennogo mneniya: ekonomicheskie i social'nye peremeny] 6 (2020) 231-265.

DOI: https://doi.org/10.14515/monitoring.2020.6.1778I. $\underline{\mathrm{O}}$

[9] EEAS special report update: short assessment of narratives and disinformation around the COVID19 pandemic (update may - november) [Jelektronnyj resurs]. URL: /https://euvsdisinfo.eu/ru/ (accessed: 05.12.2021).

[10] V.V. Gricenko, A.D. Reznik et al., Fear of coronavirus disease (COVID-19) and basic beliefs of the individual, Clinical and special psychology [Klinicheskaja i special'naja psihologija] 2(2) (2020) 99-118.

[11] Wordstat.yandex [Electronic resource]. URL: https://wordstat.yandex.ru/ (accessed: 02.12.2021).

[12] Yu.A. Saitbattalova, The functioning of author's neologisms in Internet communication
[Funkcionirovanie avtorskih neologizmov v internet-kommunikacii], Materials of the AllRussian Scientific and Practical Conference with International Participation for Young Scientists [Materialy Vserossijskoj nauchno-prakticheskoj konferencii s mezhdunarodnym uchastiem dlya molodyh uchenyh], BASHGU Editorial and Publishing Centre, Ufa, 2018, pp. 166-169.

[13] Mirror.co.uk [Electronic resource]. URL: https://www.mirror.co.uk/news/us-news/doctorsays-young-covid-patients-24589635 (accessed: 29.11.2021).

[14] Official website of the Ministry of Internal Affairs of the Russian Federation [Electronic resource]. URL: https://news.mail.ru/company/mvd/ (accessed: 11/29/2021). 